\title{
Experimental Research Of “Ghost” Escherichia Coli O 104 Vaccine
}

Daniela Vasileva Pencheva ${ }^{1 *}$, Elena llieva Velichkova ${ }^{1}$, Denis Zdravkov Sandarov², Adrian Draganov Cardoso ${ }^{2}$, Maria Hristova Mileva ${ }^{3}$, Petia Dinkova Genova$\mathrm{Kalou}^{4}$ and Rayna Bryaskova ${ }^{5}$

${ }^{1}$ BB-NCIPD, 1504 Sofia, 26 Yanko Sakazov blvd., Bulgaria

2Sofia University "St. Kliment Ohridski”, Faculty of Biology, 1164 Sofia, 8 Dragan Tsankov Blvd, Bulgaria

${ }^{3}$ Veterinary clinic "Zoocenter", Sofia, Bulgaria

${ }^{4}$ National Centre of Infectious and Parasitic Diseases, 1504 Sofia, 26 Yanko Sakazov blvd, Bulgaria

5UCTM, 8 "St. Kliment Ohridski" blvd, 1756 Sofia, Bulgaria

*Corresponding author: Pencheva DV, BB-NCIPD, 1504 Sofia, 26 Yanko Sakazov blvd, Bulgaria, Tel: 359 888360021; E-mail: dani_pencheva@abv.bg

Received date: Dec 04, 2014; Accepted date: Jul 09, 2015; Published date: Jul 13, 2015.

Copyright: (c) 2015 Pencheva DV, et al. This is an open-access article distributed under the terms of the Creative Commons Attribution License, which permits unrestricted use, distribution, and reproduction in any medium, provided the original author and source are credited.

\begin{abstract}
"Ghost" vaccines are an innovative idea to obtain better results of immunization due to the presence of fuller spectrum of saved antigenic determinants and development of protective immunity. E.coli $\mathrm{O} 104$ was tested with the aim to be studied as potential ghost vaccine. For this purpose, the strain E.coli 0104 was inactivated by silver nanoparticles (AgNps) stabilized in polyvinyl alcohol (PVA) in order to produce "ghost" cells. An experiment with rabbits immunized with E.coli O 104 antigen treated according to the classical heat treatment method and other E.coli O 104 antigen inactivated with the tested AgNps/PVA hybrid material showed the advantage of the second used inactivated antigen. It was established that the specific titer of the immunized with "ghost" cells rabbit which were obtained by inactivated with AgNps/PVA antigen was earlier achieved and the protective immunity was equivalent to that of processed antigen according to a classical methodology.
\end{abstract}

Keywords: E. coli O 104; Ghost vaccine; Hybrid material; Silver nanoparticles

\section{Introduction}

The outbreak from E. coli O 104:H4 in Germany and other EU/EEA countries was one of the largest reported HUS outbreaks in the world. Verotoxigenic E. coli (VTEC) that produce AE (Attaching and Effacing) lesions on enterocytes are EHEC (enterohaemorrhagic E.coli). The enterroaggregative Verotoxin (Vtx-) producing E. coli strain serotype $\mathrm{O}$ 104: $\mathrm{H} 4$ has often been described as an enterrohaemorrhagic E.coli (EHEC). The identification of $E$. coli O 104 as enteroaggregative $E$. coli (EAggEC)/VTEC radically modified the epidemiological perspective and investigations. The interesting fact is that the primary sources and vehicles of typical EHEC infections in humans are ruminants, whereas no animal reservoir has been identified for enteroaggregative E. coli [1]. The Verotoxigenic E.coli serogroup O 104 has been reported three times as isolate from animals and food by the EU member states. Two of the isolations were from cattle and the detected serotypes were O 104:H12 and O 104:H21. VTEC serotype O 104 was isolated also from wild boar. From sheep and young cattle was isolated O 104:H7. In food VTEC O 104 was isolated from bovine carcasses and meat [2]. When infecting humans VTEC can also be responsible for HUS (Hemolytic - uremic syndrome) due to the production of Vtx. E. coli O 104:H21 was also agent of sporadically outbreaks. Although the main agent of two HUS cases in German was E. coli O 104:H4 VTEC strain [1].

The aim of the present investigation is the inactivation of the bacterial strain E. coli O 104 with AgNps stabilized by PVA in order to be obtain "ghost" cells with preserved integrity of the cell surface. The use of "ghost" vaccines is perspective approach for obtaining of vaccines, which guarantees fuller spectrum of saved antigenic determinants and presence of protective immunity [3-5].

\section{Materials and Methods}

\section{Materials}

Polyvinyl alcohol (PVA) (Sigma-Aldrich; 87-88\% hydrolyzed, $\mathrm{Mw}=13000-23000 \mathrm{~mol}^{-1}$ ) and silver nitrate (AcrosOrganics) were used as received without further purification. Escherichia coli serotype O 104, Californian rabbits and nutrient media were obtained via "Bul Bio-NCIPD".

Mouse fibroblast cells (L20B cell line), were cultivated in MEM growth medium (Sigma-Aldrich) supplemented with 15\% FBS (Gibco), $100 \mathrm{U} / \mathrm{ml}$ penicillin $\mathrm{G}$ sodium and $100 \mu \mathrm{g} / \mathrm{ml}$ streptomycin sulphate (Sigma-Aldrich). For routine passages monolayers were detached using a mixture of $0.05 \%$ trypsin (Gibco)-0.02\% ethylendiamino tetraacetic (EDTA) (Sigma-Aldrich). Cell viability was estimated by the MTT [3-(4,5-dimethylthiazol-2-yl)-2,5diphenyltetrazolium bromide] (Sigma-Aldrich).

\section{Methods}

Transmission electron microscopy (TEM) images were recorded on a FEG-TEM (Phillips CM 200 field emission gun TEM). Samples were prepared by spin coating of the precursor solutions on carbon- coated grids using a microprocessor controlled spin coater (Model GP3-8 Spincoat, PI-KEM Ltd., UK) and dried under air at room temperature. TEM observations of the films were performed by annealing of the coated grids at $100^{\circ} \mathrm{C}$ for $1 \mathrm{~h}$. UV-Vis absorption spectra of the hybrid films and solution were recorded at room temperature in the 
wavelength range from 200 to $800 \mathrm{~nm}$ using Perkin Elmer Lambda UV-Vis-NIR spectrophotometer.

Synthesis of silver nanoparticles via thermal reduction using Polyvinyl alcohol as a stabilizer: Synthesis of silver nanoparticles stabilized in PVA was performed as described previously [6]. In brief, five grams of polyvinyl alcohol (PVA) was dissolved in $95 \mathrm{ml}$ deionized water under stirring at $80^{\circ} \mathrm{C}$. Silver nitrate $(30 \mathrm{mg}$ ) dissolved in $5 \mathrm{ml}$ (water) is added drop-wise under stirring to $95 \mathrm{ml}$ of PVA solution (5\%) thus achieving final concentrations of silver nitrate in the solution equal to $300 \mathrm{mg} / \mathrm{l}$. The prepared solutions were heated for $1 \mathrm{~h}$ at $100^{\circ} \mathrm{C}$ in dark thus leading to the formation of silver nanoparticles (AgNps) stabilized via PVA. The color of the solution was brown. The concentration of the silver after thermal reduction was established by ICP as $174 \mathrm{mg} / \mathrm{l}$.

Determination of minimal bactericidal concentration (MBC): The MBC was determined with the method of macrodilutions [7]. The PVA/AgNps solution $(174 \mathrm{mg} / \mathrm{l})$ was diluted with injection water at 1:6 ratio thus leading to starting concentration of $29 \mathrm{mg} / \mathrm{l}$. In five sterile tubes, successively falling two-fold dilutions starting from a working dilution of PVA/AgNps in a volume of $1 \mathrm{ml}$ with injection water to a concentration of $0.45 \mathrm{mg} / \mathrm{l}$ were performed. To each tube was added a quantity of the bacterial suspension (by patented methodology) [8] to provide from 105 to 106 CFU (Colonies Forming Units) of them. From a suspension the related positive control was seeded by the same amount of surface method on agar plates with Soybean Casein Agar (SCA). Tubes and plates were placed for 24 hours at $32.5 \pm 2.5^{\circ} \mathrm{C}$. From each tube was plated by agar surface plate method on plate with SCA (Soya Casein Digest Agar), which were cultured in a thermostat at $32.5 \pm 2.5^{\circ} \mathrm{C}$ in order to confirm inactivation of the bacterial suspension.

Cytotoxicity analysis: Cell viability was estimated by a modification of the MTT [3-(4,5-dimethylthiazol-2-yl)-2,5diphenyltetrazoliumbromide] assay [9], which determines the metabolically active mitochondria of cells. Compound was evaluated for in vitro cytotoxicity against mouse fibroblast cell line (L20B). Confluent monolayer was covered with media containing the tested compound in concentrations from $50 \mu \mathrm{g} / \mathrm{ml}$ to $0,00001 \mu \mathrm{g} / \mathrm{ml}$ and cultured at $37^{\circ} \mathrm{C}$ for $24 \mathrm{~h}$ and $48 \mathrm{~h}$. After incubation, the medium was replaced with MTT for further $3 \mathrm{~h}$ incubation. Then, the MTTformazan product was solubilized in ethanol:DMSO (1:1), and the optical density was measured at a test wave length of $540 \mathrm{~nm}$. Using dose-response curves the concentration of tested compound able to reduce cell viability on the $24 \mathrm{~h}$ and $48 \mathrm{~h}$ with $50 \%$ (CD50) was determined.

Immunization procedure: Two rabbits were immunized parallelly with Escherichia coli $\mathrm{O} 104$ antigen, processing in "ghost" cells. A standardized to $109 \mathrm{CFU}$ bacterial suspension was separately treated with the PVA/AgNps solution, added in an amount that is in a silver concentration of $30 \mathrm{mg} / \mathrm{l}$ in the final volume of the antigen. The used antigen for immunization in the first rabbit was washed aseptically with saline in order to remove excess of the PVA/AgNps. By centrifugation and re-standardization of the resulting ghost $E$. coli $\mathrm{O}$ 104 cell the antigen is standardized again. The used in the second rabbit antigen for immunization Escherichia coli O 104 was inactivated with heat. Confirmed inactivated bacterial suspension of standardized in densitometer to $3 \mathrm{MF}$ was used as an antigen for immunization of both rabbits. Intravenous immunizations were carried out with increasing antigenic load of 0.5 to $2 \mathrm{ml}$ on Californian rabbits: immunization in vena marginalis in intervals of 3 to 4 days.
An attempt was made infecting with $1 \mathrm{ml}$ of a billionth suspension of alive bacterial cells Escherichia coli O 104 per os of rabbits 1 week after the last immunization with the intention to prove presence of protective immunity and titration of the received rabbits antiserum.

\section{Results and Discussion}

The strategy of the present study was to create "ghost" cells with preserved integrity of the cell surface using silver nanoparticles as an innovative and no expensive approach. For this purpose, silver nanoparticles stabilized in PVA were prepared according to reported in the literature method [6].

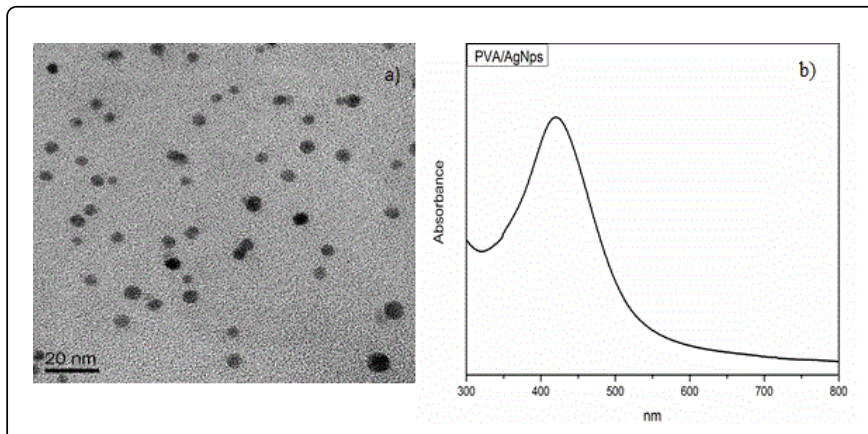

Figure 1: (a) TEM image of PVA/AgNps; (b) UV-vis spectrum of PVA/AgNps.

The formation of silver nanoparticles in the synthesized hybrid material (silver concentration of $174 \mathrm{mg} / \mathrm{l}$ ), was evidenced by TEM and UV analysis. Spherical silver nanoparticles with an average diameter of $5.0 \pm 1.0 \mathrm{~nm}$ have been measured by TEM and their formation was confirmed using UV-Vis spectroscopy by the appearance of strong absorption bands at $420 \mathrm{~nm}$ (Figure 1). The maximal nontoxic concentration (MNC) which is the maximal concentration, which altered neither the morphology of monolayer nor the cell survival rate, was detected at $0.007 \mathrm{mg} / \mathrm{l}$ silver concentration. The $\mathrm{CD}_{50}$ was determined at $0.53 \mathrm{mg} / \mathrm{l}$ silver concentration using dose-response curve. The value of therapeutic efficacy (TE) was 75.71 (Figure 2).

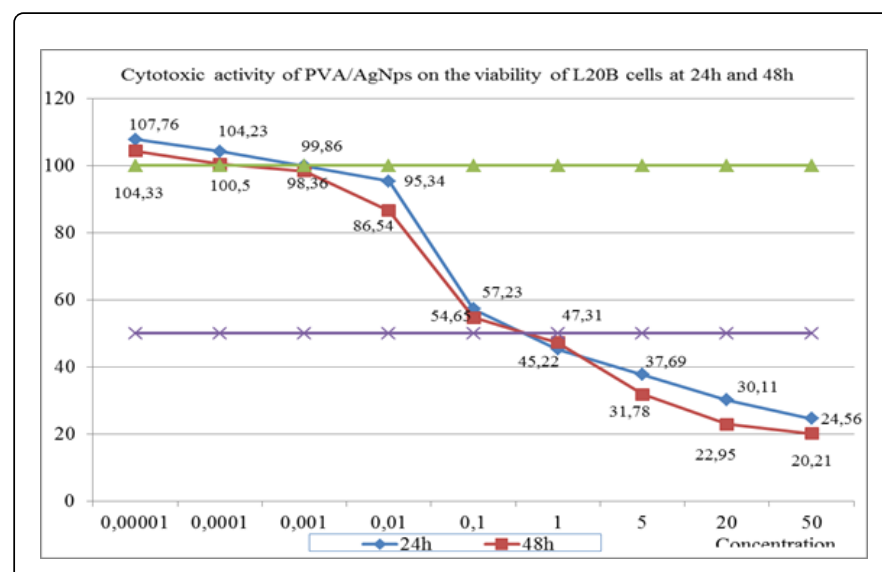

Figure 2: Cytotoxic activity of PVA/AgNps on the viability of L20B cells at $24 \mathrm{~h}$ and $48 \mathrm{~h}$. 
Specified minimal bactericidal concentration (MBC) and some evidences of therapeutically efficiency (TE) can determine the secure intravenous administration of the vaccine suspension. The determined MBCs of $E$. coli $\mathrm{O} 104$ were $0.054 \mathrm{mg} / \mathrm{l}$. The estimated MBC value of $E$. coli $\mathrm{O} 104$ demonstrated sensitivity to silver, as tests with the same hybrid material showed that MBC values equal or more than $1.1 \mathrm{mg} / \mathrm{l}$ are sign for silver resistance [10].

For the inactivation process, PVA/AgNps solution with silver concentration of $30 \mathrm{mg} / \mathrm{l}$ was used, since the standard method for determining the $\mathrm{MBC}$ as described in CLSI concerns a starting concentration of $10^{5}$ to $10^{6}$, and the bacterial culture was standardized to a billionth suspension for the purposes of the experiment. The process of inactivation was confirmed by culture procedures, where the suspension was seeded by the surface agar method with incubating and reading that proved the absence of bacterial growth. Both of rabbits, which were selected from one litter in order to provide closely related signs and immunity, have passed the full course of four immunizations with increasing antigenic load of $E$. coli $\mathrm{O} 104$. One of rabbits was immunized with the antigen prepared in a conventional manner. The other rabbit was immunized with the antigen inactivated by the hybrid material. Titers of specific anti- E. coli O 104 agglutinins during and after completion of the immunization cycle were determined (Table 1).

\begin{tabular}{|l|l|l|l|l|l|}
\hline & $\begin{array}{l}\text { Titer 3 days } \\
\text { after the first } \\
\text { immunization }\end{array}$ & $\begin{array}{l}\text { Titer 3 days } \\
\text { after } \\
\text { second } \\
\text { immunization }\end{array}$ & $\begin{array}{l}\text { Titer 3 days } \\
\text { after the third } \\
\text { immunization }\end{array}$ & $\begin{array}{l}\text { Titer 3 days } \\
\text { after the fourth } \\
\text { immunization }\end{array}$ \\
\hline $\begin{array}{l}\text { Rabbi } \\
\text { t No 1 }\end{array}$ & Without titer & $\begin{array}{l}\text { At 1:50 dilution } \\
\text { good positive } \\
\text { slide } \\
\text { agglutination }\end{array}$ & $\begin{array}{l}\text { At 1:400 dilution } \\
\text { good positive } \\
\text { slide agglutination }\end{array}$ & $\begin{array}{l}\text { At 1:400 dilution } \\
\text { very gositive sood } \\
\text { agglutination }\end{array}$ \\
\hline $\begin{array}{l}\text { Rabbi } \\
\text { t No 2 }\end{array}$ & Without titer & Without titer & $\begin{array}{l}\text { At 1:50 dilution } \\
\text { very gon good } \\
\text { positive slide } \\
\text { agglutination }\end{array}$ & $\begin{array}{l}\text { At 1:400 dilution } \\
\text { very gositive sood } \\
\text { agglutination slde }\end{array}$ \\
\hline
\end{tabular}

Rabbit No1-Immunized with antigen treated with hybrid material.

Rabbit No 2-Immunized with antigen treated with heat.

Table 1: Determination of the specified antibody against E.coli O 104 during and after the end of immunization scheme.

It was established that the rabbit immunized with "ghost" bacterial cells forms more rapidly titre of specific antibodies from those that has been immunized with the antigen treated by the classical method. The presence of a specific titer after the second immunization was observed only at the antigen treated with the PVA/AgNps which was applied for the immunization of the rabbit No 1 (Table 1). It is known that a traditional production of non-living (killed) vaccine by heat treatment, irradiation or chemical treatment of the pathogen often leads to denaturation of significant structural components of the cell wall, changing the antigenic character of the vaccine due to the loss of important immunogenic epitopes cannot create a complete immunity [11]. The used for inactivating higher concentration of PVA/AgNps $(30 \mathrm{mg} / \mathrm{l})$, which has been applied successfully in our previous studies [12], did not effect on the vitality of the tested animal, since the excess of the PVA/AgNps hybrid material was removed partically in advance.

After the infection per os of the immunized rabbits with $1 \mathrm{ml}$ of a billionth suspension of alive bacterial cells $E$. coli $\mathrm{O} 104$, they showed a mild discomfort during the next day with transient loss of appetite. After this period, rabbits recovered without clinical signs of disease.

\section{Conclusion}

The rabbit immunized with "ghost" bacterial cells formed faster titre (even after the second immunization) of the specific antibodies in comparison to those immunized with antigen treated by classical methodology. It has been proven advantage when using antigen, inactivated by the PVA/AgNps hybrid material for the preparation of ghost cells to such treated by classical methodology by heat inactivation expressed in faster development of specific titer. Obtained by the treatment of the antigen for immunization with PVA/AgNps ghost vaccine creates protective immunity, equivalent to that of processed antigen according to a classical methodology with heat inactivation. The TE was established as very good, which allows the use of the hybrid material without expecting pathological changes in cells.

\section{Acknowledgments}

We express our gratitude for the support of BB-NCIPD, NCIPD and UCTM.

\section{References}

1. Pierard D, De Greve H, Haesebrouck F, Mainil J (2012) O157:H7 and O104:H4 Vero/Shiga toxin- producing Escherichia coli outbreaks:respective role of cattle and humans. Veterinary research 43:13.

2. Shiga toxin/verotoxin-producing Escherichia coli in humans, food and animals in the EU/EEA, with special reference to the German outbreak strain STEC O104.

3. Szostak M, Hensel A, Eko F, Klein R, Auer T et al. (1996) Bacterial ghosts: nonliving candidate vaccines. J Biotechnol 44: 161-170.

4. Pencheva D, Bryaskova R, Genova-Kalou P (2014) Properties and possibilities for application of the hybrid material with silver nanoparticles (PVA / AgNps), Proceeding of 9 workshop "Biological activity of metals, synthetic compounds and natural products" November 26-28, Institute of Experimental Morphology, Pathology and Anthropology with Museum (IEPAM) under the auspices of the Bulgarian Academy of Sciences, p.38-54.

5. Haslberger A, Kohl G, Felnerova D, Mayr U, Furst-Ladani S et al. (2000) Activation, stimulation and uptake of bacterial ghosts in antigen presenting cells. J Biotechnol 83: 57-66.

6. Pencheva D, Bryaskova R, Kantardjiev T (2012) Polyvinyl alcohol/silver nanoparticles (PVA/AgNps) as a model for testing the biological activity of hybrid materials with included silver nanoparticles, Materials Science and Engineering C 32: 2048-2051.

7. CLSI M26-A (Clinical \& Laboratory Standards Institute) (1999) Methods for Determining Bactericidal Activity of Antimicrobial Agents. Approved Guideline, vol.19, no. 18 .

8. Pencheva D (2014) Method for preparation of a suspension with guaranteed content of culturable microorganisms. Application for a patent and for invention. Patent Office of the Republic of Bulgaria.

9. Mosmann T (1983) Rapid colorimetric assay for cellular growth and survival: application to proliferation and cytotoxicity assays. J Immunol Methods 65: 55-63.

10. Iliev M (2013) “Antimicrobial's resistant Salmonella strains, tested for susceptibility to hybrid material with included silver nanoparticles". Problems of infectious and parasitic diseases 41.

11. Jalava K, A Hensel, M Szostak, S Resch and W Lubitz (2002) Bacterial ghosts as vaccine candidates for veterinary applications. J Contr Rel 85: $17-25$. 
Citation: Pencheva DV, Velichkova EI, Sandarov DZ, Cardoso AD, Mileva MH, et al. (2015) Experimental Research Of "Ghost" Escherichia Coli O 104 Vaccine. J Vaccines Vaccin 6: 288. doi:2157-7560.1000288

Page 4 of 4

12. Pencheva D, Kantardjiev T, Bryaskova R (2011) Possibilities for application of hybrid materials with silver nanoparticles for prevention and treatment of animals. The Jubilee Scientific Session "110 years
National Diagnostic Science-and-Research Veterinary Medical Institute", pp: 329-333. 